\title{
Attitudes of School Teachers in the State of Kuwait Towards the Experience of Distance Education During the Coronavirus Pandemic
}

\author{
Dr. Ahmad Ibrahim Al-Houli ${ }^{1}$, Dr. Talal Ibrahim Al-Mesad ${ }^{1} \&$ Dr. Eisa Mohammed Al-Kandari ${ }^{1}$ \\ ${ }^{1}$ The Public Authority for Applied Education and Training, College of Basic Education, Department of Educational \\ Foundations and Administration, Kuwait \\ Correspondence: Dr. Ahmad Ibrahim Al-Houli, The Public Authority for Applied Education and Training, College \\ of Basic Education, Department of Educational Foundations and Administration, Kuwait.
}

Received: September 4, 2021

Accepted: October 7, 2021

Online Published: October 8, 2021

doi:10.5430/ijhe.v11n2p82

URL: https://doi.org/10.5430/ijhe.v11n2p82

\begin{abstract}
This study aimed to identify the attitudes of public school teachers in the State of Kuwait at various educational stages towards the experience of distance education during the COVID-19 pandemic.

The descriptive approach was applied; a questionnaire consisting of four dimensions was developed to measure teachers' attitudes towards distance education. The study sample consisted of 1028 teachers of various disciplines at all levels of education in public schools in the State of Kuwait. The results indicated that teachers had a higher degree of positive attitudes towards the distance education experience. The results also showed that there were statistically significant differences between the study sample members due to each of the following variables: the educational district and the educational stage.

The results did not show statistically significant differences due to the gender variable. Additionally, the results did not show the existence of statistically significant differences due to the variable years of experience on the total degree and dimensions of scale, except for the dimension "student assessment through distance learning using the TEAMS Program" attributed to the experience category ( $1-5$ years).
\end{abstract}

Keywords: attitudes, distance education, coronavirus pandemic

\section{Statement of Study Problem}

Many countries have turned to the method of distance education for all school levels, finding it a catalyst for developing the teaching and learning process. The restrictions imposed by the coronavirus pandemic accelerated the process. Several countries in the world have adopted the distance education method as an alternative method to traditional education in light of the pandemic to ensure the safety of teachers, students, and their families (Al-Mesad, 2020). The experience of distance education in educational institutions in the State of Kuwait is one of the most important challenges the state faced at all the different stages of education. The Ministry of Education adopted distance education in public and private schools as an initial step, while it supervised teachers' training to use the TEAMS program. This program's effectiveness has been proven in many countries. Additionally, the ministry prepared plans to train students at all levels and to involve parents to interact with the educational process to strive for the success of distance education by all available means.

The sudden and rapid adoption of a relatively new concept like distance education may pose disadvantages as well as advantages, affecting the impressions and attitudes of its users. Therefore, it was considered necessary to carry out an evaluation of the experience and obtain feedback from executive authorities, namely teachers, a year and a half after the adoption. This study collected data from public school teachers to understand their views of their distance education experience. After collecting their observations, their satisfaction with and acceptance of distance education as an educational body was measured. The results indicated the degree of success of the adoption of distance education in light of the difficult circumstances the pandemic created.

\subsection{Study Questions}

RQ1: What are public school teachers' attitudes in the State of Kuwait towards the distance education experience during the coronavirus pandemic? 
RQ2: Are there statistically significant differences among the attitudes of school teachers in the State of Kuwait due to the study variables (gender, educational stage, educational district, and years of experience)?

\subsection{Objectives of the Study}

1) Identifying the attitudes of public school teachers in the State of Kuwait towards the distance education experience during the coronavirus pandemic

2) Revealing the extent to which there are statistically significant differences between the attitudes of school teachers in the State of Kuwait due to the study variables (gender, educational stage, educational district, and years of experience)

\subsection{The Significance of This Study}

In this study, the researchers sought to identify the views of teachers in public schools at all educational levels about the experience of distance education in the State of Kuwait during the coronavirus pandemic. The significance of the study lies in the fact that teachers are the main element responsible for conveying information to learners in an effective and appropriate manner. Because of their knowledge and experience of the best methods of teaching, their views are very important. The researchers also argued that teachers' opinions highlight the strengths and weaknesses of distance education as a new experience during the crisis and provide an opportunity for those in charge of the educational process in the State of Kuwait to improve and develop the process by addressing its weaknesses and shortcomings and avoiding mistakes in the future.

The researchers proposed that the results of the study are in the interest of officials and decision-makers aiming to improve the efficiency of distance education and its impact on the educational achievement of students over the past year and a half. At the same time, this study may contribute to encouraging those in charge of the educational process to make some adjustments to educational policies in line with distance education programs. Finally, the importance of the study is evident from its contribution to raising the educational level of students by collecting teachers' opinions on adopting primary or supplementary teaching methods for regular education. New and different teaching methods from those used in regular education are needed to keep pace with the progress in the world in general and in the educational field in particular. Modern technology needs to be incorporated into education.

\subsection{Study Limits}

1) Subjective limits: The study was limited to obtaining the views of teachers of the Ministry of Education in the State of Kuwait on the experience of distance education during the coronavirus pandemic.

2) Spatial boundaries: The schools of the Ministry of Education in the six educational districts in the State of Kuwait (Al-Asma Educational District, Hawally Educational District, Al-Farwaniyah Educational District, Al-Jahra Educational District, Mubarak Al-Kabeer Educational District, and Al-Ahmadi Educational District).

3) Time limits: The first semester of the academic year 2020/2021.

4) Human limits: The study was limited to school teachers in the Ministry of Education working at all academic levels.

\subsection{Study Terminologies}

- Attitudes: The acquired predispositions and tendencies formed through accumulated cognitive and behavioural experiences, which lead to the individual having negative or positive responses to various aspects of life (Al-Mujaidil \& Al-Sharia, 2012).

- Distance education: "The process of transferring knowledge to the learner at his place of residence or work instead of the learner's transfer to the educational institution. It is based on the delivery of knowledge and skills of the educational material to the learner away from or separated from the teacher or based on the educational process, and technology is used to fill the gap between each of the two parties by simulating face-to-face contact" (UNESCO, 2020, p. 54).

- TEAMS Program: A communications and business platform owned by Microsoft that is part of the Microsoft 365 programs. The TEAMS program began in 2016 to organize high-quality electronic communication between individuals. The program provides distance learning chatting, messaging, interactive live workspaces, live video conferencing, and interactive storage and file storage for teachers and learners (Warren, 2016). 


\section{Theoretical Framework}

\subsection{Introduction}

Distance education has become an urgent necessity, especially during the coronavirus pandemic. The pandemic began at the end of 2019 and swept across the world, forcing many countries to change their educational, economic, political, social, and other policies to avoid its deadly effects (Al-Mesad, 2020; Cao et al., 2020). It was necessary to implement distance education as a convenient alternative to traditional school education.

\subsection{The Concept of Distance Education}

Distance education is one of the modern education strategies that represent the development in educational technology and teaching methods. Distance education is based on the concept of separating the teacher from the learner, changing the traditional environment of education. Technology and its tools play the role of mediator and link between teacher and students. There is no doubt that this unconventional concept has contributed to changing the image of traditional direct education to a new image in which the teacher is separated from the learner and the learner is separated from the school environment and in which there is total dependence on technology and the internet to obtain information. Thus, in this modern educational process, teachers have had to use various digital tools and resources to solve problems as well as use new methods and means of teaching (Eickelmann \& Gerick, 2020).

Al-Sharhan (2014) defined open and distance learning as "that type of learning which is characterized by the lack of total direct communication between the faculty (supervisors) and learners, where educational materials are provided through the local or global network (the internet) through the use of educational technology and communication" (p. 2).

UNESCO (2020) indicated that there are two types of distance learning: The first is simultaneous education, which involves confronting the teacher and learner at the same time in a real educational environment through modern technological means that allow direct dialogue and discussion. The second type is asynchronous learning, which involves directing the learner through electronic sources. The learner uses these sources to acquire information without direct or simultaneous contact with the teacher (UNESCO, 2020).

In UNESCO's vision, it is clear that all technological fields are used in distance education that can help deliver information quickly and effectively. Technological development plays a role in this process (UNESCO, 2020).

\subsection{Justifications for Applying Distance Education}

Al-Sharhan (2014) indicated that there are factors and justifications for adopting open and distance education in response to factors that call for the development of universities in line with local and global conditions. These justifications are,

- Global trends and recommendations: Global trends and recommendations of organizations specialized in the development of education according to global attitudes in developed countries regarding open education.

- Social and cultural justifications: Distance education is a way to help members of society who find it difficult to leave their homes or even join regular universities, as well as help workers and part-time students study without interrupting their work.

- Human and geographical justifications: The increase in the population has put great pressure on educational institutions. Through distance education, it is possible to absorb large numbers of students at the same time.

- Humanitarian and psychological justifications: Educational opportunities can be provided to everyone who seeks it, regardless of their circumstances and without requiring high-cost educational methods that do not meet modern educational needs.

- Economic justifications: The economic situation of some countries is difficult given the absence of sources of livelihood and education and the low standard of living. All of these reduce the rate of traditional higher education. Not receiving adequate education negatively affects the development of the human element in these countries.

- Political justifications: Political turmoil in countries or among countries can lead to the closure of educational institutions of all kinds. 


\subsection{Advantages of Distance Education}

- Distance education helps develop the cultural, scientific, and social aspects of learners.

- It compensates for the shortage of teaching staff.

- It reduces the impact of the lack of capabilities of some higher education institutions.

- It takes into account individual differences among learners by providing them with various educational resources and different techniques and means of education.

- Distance education is considered an opportunity for those who wanted to complete their education or who missed out on education in the early stages of their lives. It allows them to combine work and study.

- Distance education helps the learner develop in a skilful and academic way because the focus is on academic content only.

- Distance education increases self-reliance because learners themselves choose the sources from which to derive information without direct dependence on the teacher (Al-Hiyari, 2020).

\subsection{Obstacles to Distance Education}

It is normal for any of the various technological means that are used in teaching to encounter obstacles during their application. Distance education also faces such obstacles, including teachers, students, or curricula, which may affect its success or smooth application in different educational institutions. We can summarize some of the most important obstacles in the following points:

- Adherence to traditional education and a complete lack of seriousness.

- Lack of communication between teacher and learner.

- Lack of skills and experience needed for distance education.

- Poor communication with parents.

- Rapid effect of side scatters.

- Financial constraints that prevent an appropriate educational environment from being created.

- Severe and continuous pressure on communications networks and the internet at the same time, which weakens the quality of communication.

- Lack of control over the classroom.

- Lack of motivation opportunities and difficulty of conducting time management.

- Creating an atmosphere of social isolation for individuals and students (Al-Mesad, 2020).

\subsection{Distance Education and Teachers}

When using any new technological means in teaching, emphasis should be placed on the extent of the suitability of all elements of education. For teachers, it is necessary that the technological means adopted, such as distance education, fall within their interests and capabilities to help them achieve their educational goals. In this regard, Ocal et al. (2021) found that teachers are satisfied with the diversity of educational pedagogical methods and technologies in distance education, such as images, videos, live meetings, activities, and games. Further, teachers have a degree of freedom to diversify their teaching methods using various electronic means. This has a direct impact on student motivation (Fryer $\&$ Bovee, 2016). Distance education has these advantages because it provides teachers the opportunity to choose teaching aids freely to achieve the principle of diversification. In general, regarding the extent to which teachers accept distance education, studies have proven that teachers who use the internet in their daily lives are better able to apply distance education (Ocal, et. al, 2021).

There is no doubt that teachers' success in using technology and various educational techniques has a positive impact on students' education and acquisition of experience, skills, and information. Studies have indicated that teachers' technical experiences affect educational activities, and the distance learning process enhances teachers' confidence in their basic technological skills needed to develop positive teaching attitudes. Therefore, teachers' IT skills affect the quality and success of distance education. Distance education has the effect of developing the educational level of students - sometimes, the effect is greater than that of even traditional education-because it provides an opportunity for learners to use technologies extensively (Al-Hiyari, 2020). 


\section{Previous Studies}

Al-Tarawneh (2021) conducted a study aimed at identifying the impact of the coronavirus pandemic on teachers' attitudes towards the application of different education platforms in distance education. The researcher used a measure of attitudes towards e-learning to collect data from a sample of 80 male and female teachers. The results showed that teachers had average attitudes towards using distance learning platforms. The results also showed that there were no statistically significant differences among teachers' attitudes towards the use of distance learning platforms due to the variable of gender, experience, and academic qualification in the total score. There were statistically significant differences among teachers' attitudes due to the variables of gender, experience, and academic qualification.

Abu Shkheidem et al. (2020) sought to identify the effectiveness of e-learning during the coronavirus pandemic based on the views of a group of teachers working at Kadoorie University. The researchers adopted the descriptive analytical approach, whereby questionnaire data were collected from a sample of 50 faculty members of a university that applied e-learning during the pandemic. The results showed that teachers believed the effectiveness of e-learning during the pandemic was moderate. The researchers made a set of recommendations such as establishing e-learning training courses for teachers and students and removing obstacles to e-learning.

Al-Shdeifat (2020) sought to identify the views of school principals on the reality of distance education in Mafraq Kasbah schools during the coronavirus pandemic. The researcher applied the descriptive approach. She designed a questionnaire with three domains (the cognitive domain, skill domain, and evaluation domain). The questionnaire was applied to a sample of 145 male and female principals working in Mafraq Kasbah schools. The results showed that the views of school principals about the reality of distance education during the coronavirus pandemic came to a medium degree. The results also revealed the existence of statistically significant differences among the views of the sample members due to the gender variable, in favor of females. Finally, the results showed that there were no statistically significant differences in the viewpoints of the study sample members due to the academic stage variable.

Orhan and Behan (2020) conducted a case study aimed at identifying teachers' attitudes toward and experiences of distance education during the COVID-19 pandemic. The study sample consisted of 15 teachers, from whom data were collected through a semi-structured interview. The results indicated that teachers viewed distance education as a technology-directed process and not a teaching method. Teachers were satisfied with the participation of students. Additionally, the results indicated that teachers still used the traditional method of teaching through distance education. As for teachers' attitudes towards distance education, the results indicated that the teachers had negative attitudes towards it because of the poor level of communication and interaction on the part of students.

Rahayu and Wirza (2020) sought to understand the perspectives of English education teachers on e-learning during the COVID-19 lockdown in Indonesia. The researchers focused on collecting data on three main areas (the usefulness of e-learning, the ease of e-learning, and teachers' attitudes towards e-learning). The researchers used mixed methods to collect data, namely, a questionnaire and personal interviews. The study sample consisted of 102 English language teachers working in secondary schools. The results indicated that teachers had positive views on the usefulness and ease of e-learning. The results also indicated that some of the teachers saw a decrease in the effectiveness of e-learning in general. Although the teachers were facing some obstacles during e-learning, their attitudes towards it were positive.

Shehata (2020) attempted to identify the attitudes of special education teachers towards distance education during the coronavirus pandemic and to identify the suitability of this type of education for students with special needs. The study sample consisted of 60 special education teachers. The number of deaf teachers was 20 , the number of visually impaired teachers was 20 , and the number of intellectual education school teachers was 20 . The researcher adopted the descriptive approach. She used a scale to identify the attitudes of the study sample towards distance education. The results showed that the attitudes of special education teachers towards distance education were negative. The results also showed that there were no statistically significant differences among the attitudes of the study sample by specialization, whereas there were statistically significant differences among the attitudes of the study sample by study stage.

Quneibi et al. (2020) aimed to understand the reality of e-learning in Palestine during the coronavirus pandemic from the point of view of teachers. The researchers followed the descriptive analytical approach. A questionnaire consisting of 15 items was prepared to collect data. The questionnaire had three sections (the Palestinian curriculum, Palestinian teachers and electronic training, the Palestinian technical structure and its relationship with civil society). The study sample consisted of 256 male and female teachers from the Palestinian governorates. The results of the 
study revealed that $44.1 \%$ of participants believed the Palestinian curriculum needs to be further developed to be compatible with e-learning. A total of $70 \%$ believed that teachers are in dire need of training in the use of educational platforms through a single reference. The readiness of the technical infrastructure was rated between low and medium readiness. The researchers recommended providing appropriate training to teachers, improving the technical infrastructure, and developing the Palestinian curriculum by designing educational content and appropriate teaching aids.

Wang et al. (2020) aimed at identifying the attitudes of teachers of all grades in Chinese schools towards e-learning during the coronavirus pandemic. The researchers used mixed methods (descriptive and qualitative). A questionnaire was distributed to 1450 teachers of different grades, and 20 classes of different grades that used e-learning were observed to obtain more in-depth information. The results found that teachers had positive attitudes towards e-learning during the coronavirus pandemic.

Willyian and Wati (2020) attempted to understand teachers' attitudes towards the use of communication and information technology through distance education during the coronavirus pandemic. The researchers used a questionnaire and personal interviews as tools for collecting data from a sample of 52 English language teachers working in the Language Center. The results showed that teachers had positive attitudes towards using communication technology during the coronavirus pandemic. The researchers also discussed some of the problems encountered in the use of information and communication technology in distance education.

Hinnawi and Najm (2019) aimed to reveal the degree of readiness of teachers in the city of Nablus to apply e-learning by examining their attitudes towards the use of e-learning, the degree of their competence to apply e-learning, and the number of obstacles facing its application. The researchers adopted the descriptive analytical approach. They used a questionnaire with 40 phrases distributed over three areas (competencies, attitudes, and obstacles). The questionnaire was distributed to a sample of 120 teachers chosen randomly. The results showed that the level of the three research areas (competencies, attitudes, and obstacles) was of a high degree. The results also showed that there were statistically significant differences among the responses of the sample due to the variables of age, daily use of the internet, and the number of information technology courses. A direct relationship was found between the degree of competencies and the level of the sample's attitudes towards its application. Last, a negative relationship was found between the level of obstacles to the application of e-learning and the level of participants' attitudes towards this application.

Al-Shammari (2012) aimed to identify the attitudes of mathematics course teachers towards the application of e-learning in teaching courses at the intermediate stage. The researcher adopted the descriptive approach. He conducted a questionnaire survey of a sample of mathematics teachers, numbering 147 teachers working in Hail Governorate, Kingdom of Saudi Arabia. The results showed that teachers' attitudes towards the application of e-learning in mathematics came to a medium degree. There were statistically significant differences between the attitudes of the study sample due to the educational qualification variable in favor of graduate degree holders and the years of experience variable in favor of the 5 to less than 10 years group.

Al-Shanaq and Domi (2010) examined the attitudes of a sample of students and teachers towards the application of e-learning in a science course. The researchers studied a sample of 28 male and female teachers as well as 118 male and female students from five boys' schools in the Karak governorate. Two tools were used to collect data. The first tool was a measure of teachers' attitudes, and the second tool was a measure of students' attitudes. The results showed that teachers had positive attitudes towards e-learning. Students' attitudes towards distance education were negative.

\subsection{Comments on Previous Studies}

Most of the studies that we presented above include studies conducted to identify teachers' attitudes towards distance education during the coronavirus pandemic. After examining the results, it was noted that most of the teachers' attitudes ranged between negative and medium. Consider Orhan and Behan (Orhan \& Behan, 2020) and Shehata (2020), who showed teachers' negative attitudes towards distance education. Tarawneh (2021), Abu Shkheidem et al. (2020), Al-Shdeifat (2020), and Quneibi et al. (2020) showed teachers' medium attitudes towards distance education. Only three studies showed teachers' positive attitudes towards distance education: Rahayu and Wirza (2020), Wang et al. (2020), and Willian and Wati (2020). The reason for this may be the lack of readiness of educational systems in different countries to implement distance education because of time constraints and the need to deal quickly with the need for continuity of education and to compensate for time lost after the complete closure of educational institutions along with other institutions during the pandemic. 
It is striking that most Arab studies tended to use the descriptive approach. Most studies in foreign countries adopted mixed methods, combining the descriptive and qualitative approaches, with the aim of obtaining information and studying the research issue in greater depth.

The results of previous studies on teachers' attitudes towards e-learning and distance education indicated discrepancies among them. Some of the attitudes were positive, some were moderate, and some were negative. This indicates the presence of diversity and disparity in these attitudes. Several factors may be responsible for this, including the different environments in which these studies were carried out as well as the differences in the material and human capabilities of each of those environments. These factors may play an influential role in the readiness of each environment to adopt distance education and thus may have some influence on the formation of attitudes towards education.

\subsection{Study Methodology}

The descriptive approach was adopted in the current study as well because it described the study phenomenon accurately; diagnosed, analysed, and explained it; and identified the influences and variables associated with it (Beins \& McCarthy, 2012).

\subsection{Study Population and Sample}

The study population consisted of public school teachers in the State of Kuwait who belonged to the Ministry of Education. The study area was distributed over six educational districts (Capital Educational District, Hawally Educational District, Farwaniya Educational District, Mubarak Al-Kabeer Educational District, Ahmadi Educational District, and Jahra Educational District). The number of teachers working in the Ministry of Education in the State of Kuwait is about 71,545 (Central Administration of Statistics, State of Kuwait, 2020).

The sample of the study was selected using the convenience sampling method. A total of 1028 male and female teachers working in public schools in the Ministry of Education in the State of Kuwait participated in the study.

\subsection{Study Tool Correction}

To judge the arithmetic means, the following equation was used: (Highest value in ranking - lowest value)/Number of classes $=(5-1) / 3=1.33$

2.33-1 low

$2.33-3.67$ average

$3.68-5$ high

\subsection{Study Instrument}

The researchers designed a questionnaire consisting of 39 items distributed over 4 main dimensions that measured teachers' attitudes towards the experience of distance education during the coronavirus pandemic:

- First dimension: Attitudes towards the quality of training and technical support provided by the Ministry of Education in the TEAMS program.

- Second dimension: Attitudes towards the use of the TEAMS program.

- Third dimension: Attitudes towards teaching methods in distance learning in the TEAMS program.

- Fourth dimension: Attitudes towards student assessment through distance learning in the TEAMS program.

\subsection{Instrument Validity}

Content validity was ensured by presenting the study instrument to a group of arbitrators consisting of specialized professors from a college of basic education affiliated to the public authority for applied education and training in the State of Kuwait. Their opinions were obtained about the suitability, clarity, and integrity of the instrument's language and the extent to which its items covered the objectives of the study. They were allowed to add or modify content as appropriate. In light of the arbitrators' comments, some modifications were made.

\subsection{Instrument Reliability}

The stability of the instrument's internal consistency was extracted through Cronbach's alpha. The study tool was applied to an exploratory sample with 32 faculty members from outside the main study sample (Table 1). 
Table 1. Cronbach's alpha values of the study instrument

\begin{tabular}{lll}
\hline No & Dimension & Cronbach's Alpha \\
\hline $\mathbf{1}$ & $\begin{array}{l}\text { The quality of the training programs and } \\
\text { technical support provided by the }\end{array}$ & 0.79 \\
Ministry of Education to use TEAMS & 0.77 \\
$\mathbf{2}$ & $\begin{array}{l}\text { Using TEAMS } \\
\mathbf{3} \quad \begin{array}{l}\text { Teaching methods through distance } \\
\text { learning using the TEAMS program }\end{array}\end{array}$ \\
$\begin{array}{l}\text { Assessment of students through distance } \\
\text { learning using the TEAMS program }\end{array}$ & 0.84 \\
Total Degree & 0.87 \\
\hline
\end{tabular}

The Cronbach's alpha value was 0.87 for total degree. It ranged from 0.77 to 0.84 for the dimensions, which was considered acceptable for the purposes of this study.

\section{Study Results}

The first question was, what are public school teachers' attitudes in the State of Kuwait towards the distance education experience during the coronavirus pandemic?

To answer this question, the arithmetic means and standard deviations of the attitudes of public school teachers in the State of Kuwait towards the experience of distance education during the coronavirus pandemic were extracted (Table 2).

Table 2. Arithmetic means and standard deviations of teacher attitudes towards the experience of distance education during the coronavirus pandemic in public schools in the State of Kuwait

\begin{tabular}{lllllll}
\hline No & Dimension & Mean & $\begin{array}{l}\text { Standard } \\
\text { Deviation }\end{array}$ & Rank & Attitude \\
\hline $\mathbf{2}$ & $\begin{array}{l}\text { Using TEAMS } \\
\begin{array}{l}\text { The quality of the training programs and } \\
\text { technical support provided by the } \\
\text { Ministry of Education to use TEAMS }\end{array}\end{array}$ & 4.78 & .68 & 1 & $\begin{array}{l}\text { Positive-High- } \\
\text { Positive-High- }\end{array}$ \\
$\mathbf{3} \quad \begin{array}{l}\text { Teaching methods through distance } \\
\text { learning using the TEAMS program }\end{array}$ & 3.77 & .80 & 3 & Positive-High- \\
$\mathbf{4} \quad \begin{array}{l}\text { Assessment of students through distance } \\
\text { learning using the TEAMS program }\end{array}$ & 3.59 & .79 & 4 & Moderate-Positive \\
Total Degree & 3.81 & .64 & & Positive-High- \\
\hline
\end{tabular}

Table 2 shows that the attitudes of public school teachers in the State of Kuwait regarding the distance education experience during the coronavirus pandemic was highly positive. The arithmetic average of the total degree was 3.81, and the dimension of "Using TEAMS" came in first place with an arithmetic mean of 4.13 and a standard deviation of 0.68. In last place came the field of "student assessment of students through distance learning using the TEAMS program" with an arithmetic mean of 3.59 and a standard deviation of 0.79 .

This result indicates that the distance education experience during the coronavirus pandemic was well received by teachers of public schools in the State of Kuwait working in various educational levels.

The second research question was, are there statistically significant differences among the attitudes of school teachers in the State of Kuwait due to the study variables (gender, educational stage, educational district, and years of experience)?

To answer this question, the arithmetic means and standard deviations of the attitudes of public school teachers in the State of Kuwait were extracted according to different variables (educational district, educational stage, gender, and years of experience; Table 3 ). 
Table 3. Arithmetic means and standard deviations of the attitudes of public school teachers in the State of Kuwait according to educational district

\begin{tabular}{|c|c|c|c|c|}
\hline Educational District & & No & $\begin{array}{l}\text { Arithmetic } \\
\text { Mean }\end{array}$ & $\begin{array}{l}\text { Standard } \\
\text { Deviation }\end{array}$ \\
\hline \multirow{6}{*}{$\begin{array}{l}\text { The quality of the training programs and technical support } \\
\text { provided by the Ministry of Education to use TEAMS }\end{array}$} & Al-Asma & 255 & 3.83 & .71 \\
\hline & Hawally & 218 & 3.76 & .75 \\
\hline & Al-Farwaniya & 192 & 3.81 & .77 \\
\hline & $\begin{array}{l}\text { Mubarak } \\
\text { Al-Kabeer }\end{array}$ & 131 & 3.68 & .70 \\
\hline & Al-Ahmadi & 153 & 3.71 & .76 \\
\hline & Al-Jahra & 80 & 3.90 & .65 \\
\hline \multirow{6}{*}{ Using TEAMS } & Al-Asma & 255 & 4.27 & .63 \\
\hline & Hawally & 218 & 4.12 & .64 \\
\hline & Al-Farwaniya & 192 & 4.09 & .68 \\
\hline & $\begin{array}{l}\text { Mubarak } \\
\text { Al-Kabeer }\end{array}$ & 131 & 3.97 & .75 \\
\hline & Al-Ahmadi & 153 & 4.10 & .71 \\
\hline & Al-Jahra & 80 & 4.15 & .69 \\
\hline \multirow{6}{*}{$\begin{array}{l}\text { Teaching methods through distance learning using the } \\
\text { TEAMS program }\end{array}$} & Al-Asma & 255 & 3.91 & .76 \\
\hline & Hawally & 218 & 3.69 & .74 \\
\hline & Al-Farwaniya & 192 & 3.74 & .82 \\
\hline & $\begin{array}{l}\text { Mubarak } \\
\text { Al-Kabeer }\end{array}$ & 131 & 3.65 & .86 \\
\hline & Al-Ahmadi & 153 & 3.73 & .78 \\
\hline & Al-Jahra & 80 & 3.85 & .84 \\
\hline \multirow{6}{*}{$\begin{array}{l}\text { Assessment of students through distance learning using the } \\
\text { TEAMS program }\end{array}$} & Al-Asma & 255 & 3.72 & .78 \\
\hline & Hawally & 218 & 3.46 & .72 \\
\hline & Al-Farwaniya & 192 & 3.58 & .80 \\
\hline & $\begin{array}{l}\text { Mubarak } \\
\text { Al-Kabeer }\end{array}$ & 131 & 3.47 & .85 \\
\hline & Al-Ahmadi & 153 & 3.60 & .78 \\
\hline & Al-Jahra & 80 & 3.71 & .87 \\
\hline \multirow{7}{*}{ Total Degree } & Al-Asma & 255 & 3.93 & .60 \\
\hline & Hawally & 218 & 3.75 & .59 \\
\hline & Al-Farwaniya & 192 & 3.80 & .67 \\
\hline & $\begin{array}{l}\text { Mubarak } \\
\text { Al-Kabeer }\end{array}$ & 131 & 3.69 & .68 \\
\hline & Al-Ahmadi & 153 & 3.78 & .65 \\
\hline & Al-Jahra & 80 & 3.90 & .68 \\
\hline & Total Degree & 1029 & 3.81 & .64 \\
\hline
\end{tabular}

Table 3 shows apparent differences between the arithmetic mean of the attitudes of public school teachers in the State of Kuwait according to the educational district. To determine whether these differences were statistically significant, analysis of variance was conducted (Table 7). 
Table 4. Arithmetic means and standard deviations of the attitudes of public school teachers in the State of Kuwait according to the variables of the educational stage

\begin{tabular}{|c|c|c|c|c|}
\hline Educational Stage & & No & $\begin{array}{l}\text { Arithmetic } \\
\text { Mean }\end{array}$ & $\begin{array}{l}\text { Standard } \\
\text { Deviation }\end{array}$ \\
\hline \multirow{5}{*}{$\begin{array}{l}\text { The quality of the training } \\
\text { programs and technical support } \\
\text { provided by the Ministry of } \\
\text { Education to use TEAMS }\end{array}$} & Preschool & 88 & 3.47 & .76 \\
\hline & Elementary & 383 & 3.80 & .72 \\
\hline & Intermediate & 264 & 3.79 & .76 \\
\hline & High & 294 & 3.84 & .70 \\
\hline & Preschool & 88 & 3.84 & .75 \\
\hline \multirow{3}{*}{ Using TEAMS } & Elementary & 383 & 4.14 & .66 \\
\hline & Intermediate & 264 & 4.16 & .69 \\
\hline & High & 294 & 4.18 & .66 \\
\hline \multirow{5}{*}{$\begin{array}{l}\text { Teaching methods through } \\
\text { distance learning using the } \\
\text { TEAMS program }\end{array}$} & Preschool & 88 & 3.50 & .85 \\
\hline & Elementary & 383 & 3.78 & .77 \\
\hline & Intermediate & 264 & 3.77 & .84 \\
\hline & High & 294 & 3.83 & .76 \\
\hline & Preschool & 88 & 3.38 & .87 \\
\hline \multirow{4}{*}{$\begin{array}{l}\text { Assessment of students through } \\
\text { distance learning using the } \\
\text { TEAMS program }\end{array}$} & Elementary & 383 & 3.62 & .77 \\
\hline & Intermediate & 264 & 3.62 & .82 \\
\hline & High & 294 & 3.57 & .77 \\
\hline & Preschool & 88 & 3.54 & .72 \\
\hline \multirow{3}{*}{ Total Degree } & Elementary & 383 & 3.83 & .62 \\
\hline & Intermediate & 264 & 3.84 & .67 \\
\hline & High & 294 & 3.85 & .61 \\
\hline
\end{tabular}

Table 4 shows apparent differences between the arithmetic averages of the attitudes of public school teachers in the State of Kuwait according to different educational stages. To determine whether these differences were statistically significant, analysis of variance was conducted (Table 7).

Table 5. Arithmetic means and standard deviations of the attitudes of public school teachers in the State of Kuwait according to gender

\begin{tabular}{lllll}
\hline & & No & Mean & Std. Deviation \\
\hline $\begin{array}{l}\text { The quality of the training programs and technical } \\
\text { support provided by the Ministry of Education to }\end{array}$ & Male & 109 & 3.80 & .75 \\
use TEAMS & Female & 920 & 3.78 & .73 \\
& Male & 109 & 4.15 & .68 \\
Using TEAMS & Female & 920 & 4.13 & .68 \\
Teaching methods through distance learning using & Male & 109 & 3.80 & .85 \\
the TEAMS program & Female & 920 & 3.76 & .79 \\
Assessment of students through distance learning & Male & 109 & 3.55 & .74 \\
using the TEAMS program & Female & 920 & 3.59 & .80 \\
Total Degree & Male & 109 & 3.82 & .64 \\
\hline
\end{tabular}


Table 5 shows apparent differences between the arithmetic means of the attitudes of public school teachers in the State of Kuwait according to the gender variable. To determine whether these differences were statistically significant, analysis of variance was conducted (Table 7).

Table 6. Arithmetic means and standard deviations of the attitudes of public school teachers in the State of Kuwait according to years of experience

\begin{tabular}{|c|c|c|c|c|}
\hline \multicolumn{2}{|l|}{ Experience } & \multirow{2}{*}{$\begin{array}{l}\mathbf{N} \\
303\end{array}$} & \multirow{2}{*}{$\begin{array}{l}\text { Mean } \\
3.80\end{array}$} & \multirow{2}{*}{$\begin{array}{l}\begin{array}{l}\text { Std. } \\
\text { Deviation }\end{array} \\
69\end{array}$} \\
\hline $\begin{array}{l}\text { The quality of the training } \\
\text { programs and technical support } \\
\text { provided by the Ministry of }\end{array}$ & 1 to 5 years & & & \\
\hline \multirow[t]{3}{*}{ Education to use TEAMS } & 6 to 10 years & 142 & 3.76 & .73 \\
\hline & More than 10 years & 584 & 3.77 & .76 \\
\hline & 1 to 5 years & 303 & 4.15 & .69 \\
\hline \multirow[t]{2}{*}{ Using TEAMS } & 6 to 10 years & 142 & 4.10 & .66 \\
\hline & More than 10 years & 584 & 4.13 & .68 \\
\hline \multirow{3}{*}{$\begin{array}{l}\text { Teaching methods through distance } \\
\text { learning using the TEAMS program }\end{array}$} & 1 to 5 years & 303 & 3.81 & .80 \\
\hline & 6 to 10 years & 142 & 3.75 & .79 \\
\hline & More than 10 years & 584 & 3.75 & .79 \\
\hline \multirow{4}{*}{$\begin{array}{l}\text { Assessment of students through } \\
\text { distance learning using the TEAMS } \\
\text { program }\end{array}$} & 1 to 5 years & 303 & 3.78 & .74 \\
\hline & 6 to 10 years & 142 & 3.60 & .82 \\
\hline & More than 10 years & 584 & 3.49 & .80 \\
\hline & 1 to 5 years & 303 & 3.89 & .62 \\
\hline \multirow[t]{2}{*}{ Total } & 6 to 10 years & 142 & 3.80 & .64 \\
\hline & More than 10 years & 584 & 3.78 & .65 \\
\hline
\end{tabular}

Table 6 shows apparent differences between the arithmetic means of the attitudes of public school teachers in the State of Kuwait according to the experience variable. To determine whether these differences were statistically significant, analysis of variance was conducted (Table 7). 
Table 7. Results of multiple variance analyses to examine the significance of the differences among the arithmetic means of the attitudes of public school teachers in the State of Kuwait according to the following variables: educational district, gender, experience, and educational stage

\begin{tabular}{|c|c|c|c|c|c|c|}
\hline Source & Dependent Variable & $\begin{array}{c}\text { T ype III Sum } \\
\text { of Squares }\end{array}$ & df & $\begin{array}{l}\text { Mean } \\
\text { Square }\end{array}$ & $\mathbf{F}$ & Sig \\
\hline \multirow{5}{*}{$\begin{array}{l}\text { Education } \\
\text { district }\end{array}$} & $\begin{array}{l}\text { The quality of the training programs and technical support } \\
\text { provided by the Ministry of Education to use the TEAMS }\end{array}$ & 3.783 & 5 & .757 & 1.431 & .210 \\
\hline & Using Teams & 7.794 & 5 & 1.559 & 3.447 & .004 \\
\hline & $\begin{array}{l}\text { Teaching methods through distance leaming using the (IEAMS) } \\
\text { program }\end{array}$ & 9.206 & 5 & 1.841 & 2.959 & .012 \\
\hline & $\begin{array}{l}\text { As sess ment of s tvdents through distance leaming using the } \\
\text { (TEAMS) program }\end{array}$ & 7.707 & 5 & 1.541 & 2.537 & .027 \\
\hline & Total Degree & 5.981 & 5 & 1.196 & 2.990 & 011 \\
\hline \multirow{5}{*}{ gender } & $\begin{array}{l}\text { The quality of the training programs and technical support } \\
\text { provided by the Ministry of Edveation to use the TEAMS }\end{array}$ & .006 & 1 & .006 & .012 & .912 \\
\hline & Using Teams & .074 & 1 & .074 & .164 & .686 \\
\hline & $\begin{array}{l}\text { Teaching methods through distance leaming using the (IEAMS) } \\
\text { program }\end{array}$ & .005 & 1 & .005 & .009 & .926 \\
\hline & $\begin{array}{l}\text { Assess ment of students through distance learning using the } \\
\text { (IEAMS) program }\end{array}$ & .750 & 1 & .750 & 1.235 & .267 \\
\hline & Total Degree & .122 & 1 & .122 & .305 & .581 \\
\hline \multirow{5}{*}{ experience } & $\begin{array}{l}\text { The quality of the training prog rams and technical support } \\
\text { provided by the Ministry of Education to use the TEAMS }\end{array}$ & .069 & 2 & .035 & .065 & .937 \\
\hline & Using Teams & .129 & 2 & .064 & .142 & .868 \\
\hline & $\begin{array}{l}\text { Teaching methods through distance leaming using the (IEAMS) } \\
\text { program }\end{array}$ & .417 & 2 & .209 & .335 & .715 \\
\hline & $\begin{array}{l}\text { Assess ment of stvdents through distance learning using the } \\
\text { (IEAMS) program }\end{array}$ & 14.320 & 2 & 7.160 & 11.787 & .000 \\
\hline & Total Degree & 1.752 & 2 & .876 & 2.190 & .112 \\
\hline \multirow{5}{*}{$\begin{array}{l}\text { Education } \\
\text { stage }\end{array}$} & $\begin{array}{l}\text { The quality of the training programs and technical support } \\
\text { provided by the Ministry of Education to use the TEAMS }\end{array}$ & 9.489 & 3 & 3.163 & 5.982 & .000 \\
\hline & Using Teams & 7.465 & 3 & 2.488 & 5.502 & .001 \\
\hline & $\begin{array}{l}\text { Teaching methods through distance leaming using the (IEAMS) } \\
\text { program }\end{array}$ & 7.129 & 3 & 2.376 & 3.819 & .010 \\
\hline & $\begin{array}{l}\text { As sess ment of s tvdents through distance leaming using the } \\
\text { (TEAMS) program }\end{array}$ & 2.875 & 3 & .958 & 1.578 & .193 \\
\hline & Total Degree & 6.128 & 3 & 2.043 & 5.107 & .002 \\
\hline \multirow{5}{*}{ Error } & $\begin{array}{l}\text { The quality of the training programs and technical support } \\
\text { provided by the Ministry of Education to use the TEAMS }\end{array}$ & 537.721 & 1017 & .529 & & \\
\hline & Using Teams & 459.925 & 1017 & .452 & & \\
\hline & $\begin{array}{l}\text { Teaching methods through distance leaming using the (IEAMS) } \\
\text { program }\end{array}$ & 632.875 & 1017 & .622 & & \\
\hline & $\begin{array}{l}\text { As sess ment of s tvdents through distance leaming using the } \\
\text { (TEAMS) program }\end{array}$ & 617.797 & 1017 & .607 & & \\
\hline & Total Degree & 406.806 & 1017 & .400 & & \\
\hline \multirow{5}{*}{ T otal } & $\begin{array}{l}\text { The quality of the training prog rams and technical support } \\
\text { provided by the Ministry of Edvcation to use the TEAMS }\end{array}$ & 15247.988 & 1029 & & & \\
\hline & Using Teams & 18029.700 & 1029 & & & \\
\hline & $\begin{array}{l}\text { Teaching methods through distance leaming using the (IEAMS) } \\
\text { program }\end{array}$ & 15255.012 & 1029 & & & \\
\hline & $\begin{array}{l}\text { As sess ment of s tvdents through distance leaming using the } \\
\text { (TEAMS) program }\end{array}$ & 13899.165 & 1029 & & & \\
\hline & $\begin{array}{l}\text { Total Degree } \\
\end{array}$ & 15380.590 & 1029 & & & \\
\hline
\end{tabular}

Table / shows that there were statıstically signiticant ditterences between the arithmetic means of the attitudes of public school teachers in the State of Kuwait according to the variable of educational district based on the total degree and all the dimensions except for the dimension of "the quality of the training programs and technical support provided by the Ministry of Education to use TEAMS."

The results also showed no differences among the arithmetic averages of the attitudes of public school teachers in the State of Kuwait according to the gender variable in the total degree and in all dimensions. The significance of the P values was greater than 0.05 for each case. 
There were no differences among the arithmetic averages of the attitudes of public school teachers in the State of Kuwait according to the experience variable in the total degree and in all dimensions. Distance learning using the TEAMS program, as the significance of $\mathrm{P}$ values was less than 0.05 .

There were differences among the arithmetic averages of the attitudes of public school teachers in the State of Kuwait according to the variable of educational stage in the total degree and in all dimensions (except for the dimension of "student assessment through distance learning using the TEAMS program"). The significance of P values was less than 0.05 for each case.

Scheffe test was conducted to examine the significance of the differences according to the study variable categories (Table 8).

\subsection{Education District}

Table 8. Results of Scheffe test conducted to examine the significance of the differences among the arithmetic means of the teacher attitudes of public schools in the State of Kuwait according to the educational district variable

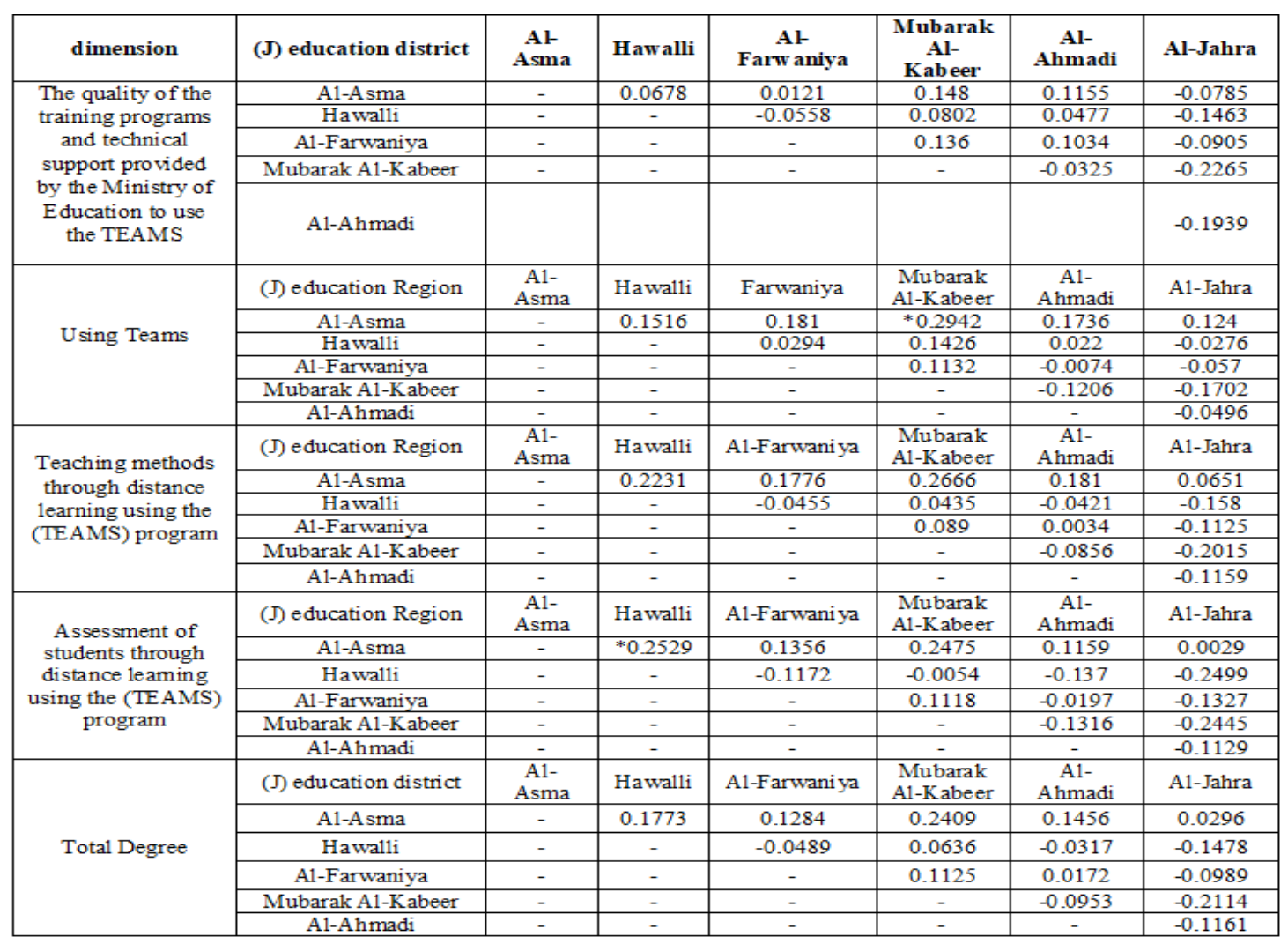

As Table 8 shows, the differences among the arithmetic averages were due to Al-Asma educational district. 


\subsection{Experience Variable}

Table 9. The results of Scheffe test conducted to examine the significance of the differences among the arithmetic means of the attitudes of public school teachers in the State of Kuwait according to experience

\begin{tabular}{|c|c|c|c|c|}
\hline $\begin{array}{l}\text { Dependent } \\
\text { Variable }\end{array}$ & (I) experience & (J) experience & Mean Difference (I-J) & Sig. \\
\hline \multirow{4}{*}{$\begin{array}{l}\text { Assessment of } \\
\text { students through } \\
\text { distance learning } \\
\text { using the TEAMS } \\
\text { program }\end{array}$} & \multirow[b]{2}{*}{$1-5$ years } & 6 to 10 years & .1800 & .076 \\
\hline & & $\begin{array}{l}\text { More than } 10 \\
\text { years }\end{array}$ & .2907 & .000 \\
\hline & \multirow[b]{2}{*}{6 to 10 years } & 1 to 5 years & -.1800 & .076 \\
\hline & & $\begin{array}{l}\text { More than } 10 \\
\text { years }\end{array}$ & .1107 & .316 \\
\hline
\end{tabular}

Table 9 shows that the differences among the arithmetic averages of the attitudes of public school teachers in the State of Kuwait according to the experience variable were attributed to the experience category (1-5 years).

\subsection{Educational Stage}

Table 10. The results of Scheffe test conducted to examine the significance of the differences among the arithmetic mean of the attitudes of public school teachers in the State of Kuwait according to the educational stage variable

\begin{tabular}{|c|c|c|c|c|}
\hline Dimensions & $\begin{array}{l}\text { Educational } \\
\text { Stage (I) }\end{array}$ & $\begin{array}{l}\text { Educational } \\
\text { Stage }(\mathbf{J})\end{array}$ & $\begin{array}{l}\text { Mean Difference } \\
\text { (I-J) }\end{array}$ & Sig. \\
\hline \multirow{9}{*}{$\begin{array}{l}\text { The quality of the training } \\
\text { programs and technical } \\
\text { support provided by the } \\
\text { Ministry of Education to use } \\
\text { TEAMS }\end{array}$} & \multirow{3}{*}{ Preschool } & Elementary & -0.3293 & 0.002 \\
\hline & & Intermediate & -0.3249 & 0.004 \\
\hline & & High & -0.3757 & 0.000 \\
\hline & \multirow{3}{*}{ Elementary } & Preschool & 0.3293 & 0.002 \\
\hline & & Intermediate & 0.0044 & 1 \\
\hline & & High & -0.0465 & 0.878 \\
\hline & \multirow{3}{*}{ Intermediate } & Preschool & 0.3249 & 0.004 \\
\hline & & Elementary & -0.0044 & 1 \\
\hline & & High & -0.0508 & 0.878 \\
\hline \multirow{9}{*}{ Using TEAMS } & \multirow{3}{*}{ Preschool } & Elementary & -0.3013 & 0.003 \\
\hline & & Intermediate & -0.3246 & 0.002 \\
\hline & & High & -0.3365 & 0.001 \\
\hline & \multirow{4}{*}{ Elementary } & Preschool & 0.3013 & 0.003 \\
\hline & & Intermediate & -0.0233 & 0.98 \\
\hline & & High & -0.0352 & 0.928 \\
\hline & & Preschool & 0.3246 & 0.002 \\
\hline & \multirow[t]{2}{*}{ Intermediate } & Elementary & 0.0233 & 0.98 \\
\hline & & High & -0.0119 & 0.998 \\
\hline \multirow{3}{*}{$\begin{array}{l}\text { Teaching methods through } \\
\text { distance learning using the } \\
\text { TEAMS program }\end{array}$} & \multirow{3}{*}{ Preschool } & Elementary & -0.2801 & 0.029 \\
\hline & & Intermediate & -0.2731 & 0.048 \\
\hline & & High & -0.3258 & 0.009 \\
\hline
\end{tabular}




\begin{tabular}{|c|c|c|c|c|}
\hline & & Preschool & 0.2801 & 0.029 \\
\hline & Elementary & Intermediate & 0.007 & 1 \\
\hline & & High & -0.0457 & 0.906 \\
\hline & & Preschool & 0.2731 & 0.048 \\
\hline & Intermediate & Elementary & -0.007 & 1 \\
\hline & & High & -0.0526 & 0.892 \\
\hline & & Elementary & -0.2872 & 0.002 \\
\hline & Preschool & Intermediate & -0.2908 & 0.003 \\
\hline & & High & -0.3033 & 0.001 \\
\hline & & Preschool & 0.2872 & 0.002 \\
\hline Total Degree & Elementary & Intermediate & -0.0035 & 1 \\
\hline & & High & -0.0161 & 0.991 \\
\hline & & Preschool & 0.2908 & 0.003 \\
\hline & Intermediate & Elementary & 0.0035 & 1 \\
\hline & & High & -0.0125 & 0.997 \\
\hline
\end{tabular}

Table 10 shows that the differences among the arithmetic averages were attributed to the primary, intermediate, and secondary stages compared with the kindergarten stage, and that the differences among the arithmetic averages were not statistically significant when compared with each other.

\section{Discussion}

The results for the first research question (What are public school teachers' attitudes in the State of Kuwait towards the distance education experience during the coronavirus pandemic?) showed that public school teachers in the State of Kuwait had a high degree of positivity towards the distance education experience during the coronavirus pandemic. These results agreed with those of Rahayu and Wirza (2020), Wang et al. (2020), Willian and Wati (2020), Hinnawi and Najm (2019), and Al-Shanaq and Domi (2010). They did not agree with those of Orhan and Behan (2020), Shehata (2020), and Quneibi et al. (2020). Regarding teachers' attitudes towards distance education, the results showed a medium attitude, in line with Tarawneh (2021), Abu Shkheidem et al. (2020), Quneibi et al. (2020), and Shammari (2012).

The results further indicated that public school teachers in the State of Kuwait had positive attitudes towards the experience of distance education during the coronavirus pandemic. This can be explained by the fact that the need for continuity of education, regardless of the means, has fostered acceptance of distance education instead of traditional education. With schools closed for several months, teachers feared for students' futures and the future of education in general in the State of Kuwait. Teachers are aware of the importance of using technology in teaching today. Various countries have made progress in adopting e-learning and educational platforms to deliver scientific knowledge to students. Many educational systems are displaying progress in their teaching methods and methods.

\subsection{Educational District}

The results showed that there were statistically significant differences among the attitudes of public school teachers in the State of Kuwait due to the variable of the educational district. Using appropriate statistical methods, it was found that the differences were attributable to the capital's educational area. The learning area of the capital is mostly inhabited by the wealthy classes of Kuwaiti society. Of course, the wealthy classes tend to use technological means and to spend money on acquiring new technologies to make their lives easier. The tendency of these classes to use technological means is high because of their frequent contact with and access to such means. This increases the possibility of teachers who fall within the geographical environment inhabited by the wealthy classes of Kuwaiti society forming positive attitudes towards the use of technology in teaching.

\subsection{Educational Stage}

The results indicated that there were statistically significant differences among public school teachers in the State of Kuwait due to the variable of educational stage. These results agreed with those of Shehata (2020), whereas they differed from those of Al-Shdeifat (2020). 
Using the appropriate statistical methods, it was found that the differences were attributed to the primary, intermediate, and secondary school stages compared to the kindergarten stage. This result was justified by the fact that these three school stages differ somewhat in the nature of their use of electronic means in teaching from the kindergarten stage. The curricula, the way students are taught, and the methods of evaluating students are completely different in the primary, intermediate, and secondary levels. Further, the age of students in kindergarten is small compared to the ages in the rest of the stages. Teachers therefore have to make more effort in managing lessons and controlling the process of communicating information to students who are at an age characterized by increased movement compared to the older age stages. The greater positive attitudes of primary, intermediate, and secondary school teachers compared to the attitudes of kindergarten teachers may be due to the difference in the method of applying distance education and the nature of the recipients of the educational contents.

\subsection{Gender}

Regarding the gender variable, the results indicated that there were no statistically significant differences among the attitudes of public school teachers in the State of Kuwait towards distance education. These results agreed with those of Tarawneh (2021), whereas they differed from those of Al-Shdeifat (2020).

The results can be explained by the fact that both sexes made up the total sample members. The justifications for the positive trend towards distance education for the sample as a whole still exist and apply to both sexes. Hence, we return to our justification for the positive attitudes of the sample as a whole: the sample members felt the necessity of continuing the teaching process after a long break. The study sample was also aware of the importance of including technology in teaching in line with modern educational attitudes.

\subsection{Years of Experience}

The results indicated that there were no statistically significant differences among the attitudes of public school teachers in the State of Kuwait in the total score and in all fields except for the field of "student assessment through distance learning using the TEAMS program." These differences were attributed to the experience category (1-5 years). These results agreed with those of Tarawneh (2021), whereas they differed from those of Al-Shammari (2012).

Considering these results, we found that the differences in teachers' attitudes were in favor of the experienced group of 1-5 years. The least experienced teachers were the ones who viewed distance education positively, as the study tool confirmed. Perhaps the reason for this result is that this group of young graduates had more opportunities to deal with technology in their university studies. Universities in the State of Kuwait have recently started using technology to a greater degree in many academic courses. Some courses require the use of technological means such as computers. The use of technology in teaching was thus second nature to them, explaining their positive attitudes towards distance education.

\section{Recommendations}

The researchers recommend the following:

- Follow-up on the development of the teacher's performance during the service, especially with regard to the use of electronic means in education.

- Training of school principals and agents on how to evaluate the performance of teachers providing distance education electronically.

- Continuous follow-up and evaluation to achieve comprehensive distance education quality.

- Events and competitions organized electronically by schools with students to ensure communication among students, schools, and guardians, and between teachers and students in particular.

- More research to evaluate distance education experience in light of the emergency conditions affecting the educational process and to search for alternatives to compensate for lost education time.

\section{Suggested Research}

The researchers suggest conducting a number of studies dealing with other educational dimensions of distance education, such as the following:

- Studies to identify the impact of distance education on teachers' job satisfaction.

- Studies to identify the relationship among teachers' skills in using technology and students' academic achievement. 
- Studies to identify parents' attitudes toward the distance education experience and its effects on the family and students.

- Comparative studies on the use of distance education among countries of the Gulf Cooperation Council.

\section{References}

Abu Shkhaidim, Sahar and Awad, Khawla and Khalila, Shahd and Al-Amad, Abdullah and Shadeed, Noor. (2020). The effectiveness of e-learning in light of the spread of the Corona virus from the point of view of teachers at Palestine Technical University (Kadoorie). The Arab Journal for Scientific Publishing, (21), 365-381.

Al-Hiyari, Iman. (2020). The pros and cons of distance education. Retrieved June 17, 2021.

Al-Msaad, Talal Ibrahim. (2020). Academic stumbling, distance learning in light of the Corona pandemic, Arabization of medicine, the Arab Center for the Authoring and Translation of Health Sciences, Kuwait 60, 60-67. October 2020.

Al-Mujaidel, Abdullah and Al-Sharia, Saad. (2012). Attitudes of students of faculties of education towards the teaching profession: A comparative field study between the Faculty of Education - Kuwait University and the Faculty of Education in Al-Hasakah - Al-Furat University as a model. Damascus University Journal, 28(4), 17-57.

Al-Sharhan, Salah Ayed. (2014). Open and distance education in the Arab world: towards development and creativity. A study submitted to: The Fourth Conference of Ministers Responsible for Higher Education and Scientific Research in the Arab World. Gulf University for Science and Technology, Kuwait.

Al-Shammari, Eid. (2012). Attitudes of mathematics teachers at the intermediate stage towards the use of e-learning in teaching mathematics and related variables. Journal of Education, 151(2), 279-305.

Al-Shanaq, Qassem and Doumi, Hassan. (2010). Attitudes of teachers and students towards the use of e-learning in Jordanian secondary schools. Damascus University Journal, 26(1+2), 235-271.

Cao, W., Fang, Z., Hou, G., Han, M., Xu, X., Dong, J., et al. (2020). The psychological impact of the COVID-19 epidemic on college students in China. Disclaimer, USA. https://doi.org/10.1016/j.psychres.2020.112934

Central Administration of Statistics. (2020). Retrieved June 15, 2021 from the Central Department of Statistics Statistics and Bulletins, Kuwait. https://doi.org/10.18356/3bf782bd-en

Eickelmann, B., \& Gerick, J. (2020). Lernen mit digitalen Medien. Zielsetzungen in Zeiten von Corona und unter besonderer Berücksichtigung von sozialen Ungleichheiten. In "Langsam vermisse ich die Schule ...". Schule während und nach der Corona-Pandemie (Vol. 16, pp. 153-162, Die Deutsche Schule, Beiheft). Münster; New York: Waxmann. https://doi.org/10.31244/9783830992318.09

Fryer, L. K., \& Bovee, H. N. (2016). Supporting students' motivation for e-learning: Teachers matter on and offline. The Internet and Higher Education, 30, 21-29. https://doi.org/10.1016/j.iheduc.2016.03.003

Hinnawi, Magdi Muhammad Rashid and Najm, \& Rawan Nidal (2019). The readiness of teachers of the first basic stage in public schools in the Nablus Education Directorate to employ e-learning "Competencies, Attitudes and Obstacles". Arab American University Journal of Research, 5(2), 102-138.

Ocal, Tugba, Halmatov, Medera, \& Ata, Samet. (2021). Distance education in COVID-19 pandemic: An evaluation of parent's, child's and teacher's competences. https://doi.org/10.1007/s10639-021-10551-x

Orhan, G., \& Behan, O. (2020). Teachers perceptions and teaching experiences on distance education through Synchronous Video conferencing during COVID-19 pandemic. Social Science and Education Research Review, 1(7), 8-44. Romania.

Quneibi, Abeer Rushdie, Ziadeh, Rana Ahmed, Rashid, Alaa Mohammed, Sanuri, Zina Walid, Zahir, Izdihar Muhammad, \& Qatina, Nasreen. (2020). The "Covid-19" pandemic: The reality of e-learning in the Palestinian context from the point of view of teachers. (unpublished report) June 2020.

Rahayu, R., \& Wizra, Y. (2020). Teachers' perception of online Learning during pandemic Covid-19. Journal of Penelitian Pendidikan, 3(20), 392-406. https://doi.org/10.17509/jpp.v20i3.29226

Shdeifat, Munira. (2020). The reality of the employment of distance education due to the Corona disease in the schools of the Mafraq Kasbah from the point of view of its school principals. The Arab Journal for Scientific Publishing, (19), 185-207. 
Shehata, Mona. (2020). Attitudes of special education teachers towards distance education in light of the Corona pandemic (Covid-19). Journal of the College of Education, 33, 469-48, Port Said University.

Tarawneh, Halima. (2021). The impact of the Corona pandemic on teachers' attitudes towards using educational platforms in distance learning. Ansaq Journal of Arts, Letters and Sciences, 2(2), 28-52.

UNESCO. (2020). Distance education: its concept, tools and strategies, a guide for policy makers in academic, vocational and technical education, King Salman College for Relief and Humanitarian Works.

Wang, P., Chen, T., Liu, J., \& Luo, H. (2020) K-12 teachers attitude towards online learning platforms during COVID-19 epidemic in China. 2020 Ninth Conference of Educational Innovation through Technology (EITT). https://doi.org/10.1109/EITT50754.2020.00010

Warren, Tom. (November 2, 2016). Microsoft Teams Launches to take on Slack in the workplace". The Verge.

Willyian, A., \& Wati, S. (2020). ICT in distance learning: Teachers attitudes and problems. ELT- Echo, 5(2), 119-136. https://doi.org/10.24235/eltecho.v5i2.6949

https://www.theverge.com/2016/11/2/13497992/microsoft-teams-slack-competitor-features

https://ieeexplore.ieee.org/document/9320647

https://doi.org/10.1016/j.iheduc.2016.03.003

https://inee.org/ar/resources/jayht-kwfyd-19-waq-altwlym-alalktrwny-fy-alswyaq-alflstyny-mn-wjht-nzr-almlmyn

\section{Copyrights}

Copyright for this article is retained by the author(s), with first publication rights granted to the journal.

This is an open-access article distributed under the terms and conditions of the Creative Commons Attribution license (http://creativecommons.org/licenses/by/4.0/). 